\title{
Patterned Inequalities and the Inequality Regime of a Swedish Housing Company
}

\section{Kristina Boréus}

Professor, Institute for Housing and Urban Research, Uppsala University, Sweden

\section{Ulf Mörkenstam}

Associate Professor, Department of Political Science, Stockholm University, Sweden

\begin{abstract}
In this article, the authors analyze inequalities between different groups of employees at a housing company in a larger Swedish city. The concept of inequality regime is taken as a point of departure. The purposes of the article are three: first, to add to knowledge of how inequality is generated at an organizational level at specific workplaces; second, to contribute to the understanding of how different practices, processes, and meanings of inequality regimes may interact to create and reinforce inequalities between natives and immigrants; and, third, to contribute to the empirical usefulness of the concept of inequality regime by demonstrating how it can be operationalized and combined with other concepts in the analysis. The study shows how the practices, processes, and meanings at the given workplace generated and reproduced different kinds of inequalities: unequal wages, an ethnic division of labor, unequal influence and job security, and unequal opportunities to capitalize on useful skills (i.e., language competence). Important conclusions are that different kinds of inequalities may reinforce each other by creating vicious circles, and subtler forms of inequality may partly explain explicit wage inequalities.
\end{abstract}

\section{KEY WORDS}

Cultural capital / discrimination / ethnocentrism / income inequality / inequality regimes / work attitudes

DOI

10.19154/njwls.v5i4.4846

\section{Introduction: patterns of inequality}

But I have a colleague here who [...] earns much less than the rest of us just because he doesn't speak or write Swedish that well, but he knows a hell of a lot more than I do about it, the things we have to fix and where to find stuff and everything like that you know, and it's assessed differently ${ }^{1}$

The statement above was made by a native-born employee at a housing company (referred to henceforth as the Housing Company) in a larger Swedish city. He was upset over inequalities at his workplace that, as he understood it, were due to the company applying irrelevant wage-setting criteria that some of his immigrant colleagues could not meet. The company had slightly more than 100 employees, of which approximately

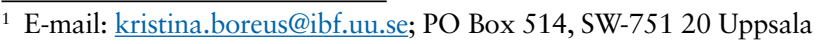


$20 \%$ had immigrated to Sweden after the age of 15 . A study of the company revealed that immigrant male employees not only earned less than their native male colleagues but that they were also disadvantaged in several other respects.

In this article, we deal specifically with inequalities at the Housing Company, as well as with two general societal patterns of inequality in Sweden and in many other countries: firstly, that some groups of non-natives in a country tend to be disadvantaged, while natives tend to be advantaged (see, e.g., Hooijer \& Picot, 2015; Kesler, 2015); secondly, that persons disadvantaged in one area often tend to be disadvantaged in other areas as well (see, e.g., Sen, 1997; SOU, 2000:41). ${ }^{2}$ Our starting point is Joan Acker's concept of inequality regime, which she defines as "loosely interrelated practices, processes, actions and meanings that result in and maintain class, gender, and racial inequalities within particular organizations" (Acker, 2006a, p. 443).

In a comparative perspective, our study is of particular interest, since Sweden is often characterized as being very good at creating opportunities for immigrants to integrate. On the Migrant Integration Policy Index, Sweden scores higher than any other country on all of the policies included in the index and has the highest possible score on the policies measured that are related to access to the labor market (MIPEX, 2015). The Swedish welfare state regime is often described as an egalitarian "inclusive incorporation regime" (Sainsbury, 2012, p. 82). Opinion polls show that positive attitudes toward immigration and cultural diversity have grown stronger over time (Demker, 2012) and that Swedes in general are highly aware of the prevalence of discrimination on the basis of ethnicity (Eurobarometer, 2012). In short, Sweden can be seen as a least likely case, that is, as the least likely country to reproduce inequality between immigrants and natives.

Although Sweden scores high on different indexes and barometers, previous research has clearly shown that immigrants are disadvantaged in relation to natives in many spheres of life, for instance in terms of health (Smith Nielsen \& Krasnik, 2010) as well as political representation, participation, and influence (Dahlstedt, 2005; Soininen, 2011). There is ethnic residential segregation (Andersson et al., 2010; Molina, 1997), with potentially negative effects on educational outcome (Szulkin \& Jonsson, 2007), and many immigrants report having been discriminated against in different contexts and feel excluded from the majority society (e.g., Kamali, 2005; Myrberg, 2007). Furthermore, the Swedish labor market is characterized by substantial ethnic workplace segregation (Åslund \& Nordström Skans, 2010), and on an aggregated level, immigrants are more often employed in subordinate and monotonous jobs with low wages (Ekberg, 2006). The division of labor involves a distribution of people into social classes that are both ethnified and gendered and thus closely related to inequality at work (Leicht, 2008). Depending on origin, immigrants can be disadvantaged to a greater or lesser extent in the Swedish labor market. Immigrants from the other Nordic countries earn almost as much as native Swedes, while immigrants from Africa, Asia, and Latin America lag behind both natives and many European immigrants (Le Grand \& Szulkin, 2002; Lundborg, 2013).

With this article, we intend to make a contribution to existing research on inequality in working-life in three ways, firstly, by contributing with knowledge about how inequality is generated at an organizational level at particular workplaces. Although, as indicated above, the patterns of inequality in the labor market are well studied, much less is known about the practices and processes that generate and perpetuate inequality between groups at Swedish workplaces (see, though, Augustsson, 1996; Mulinari, 2007; Schierup \& Paulson, 1994). Secondly, we want to deepen the understanding of 
how different practices, processes, and meanings of an inequality regime may interact to create and to reinforce inequalities between natives and immigrants at a workplace. Thirdly, the article aims at contributing to the empirical usefulness of the concept of inequality regime by demonstrating how it can be operationalized and combined with other concepts in the analysis.

We address the following research questions related to Acker's definition of "inequality regime" above: (1) How can practices and processes at the Housing Company explain specific inequalities that are found? (2) What role did local meanings play in the creation of inequality at the Housing Company? (3) How are different practices, processes, and meanings of the particular inequality regime at work at the Housing Company interrelated in creating and reinforcing the arrays of advantages/disadvantages that we found?

In the following section we explain how we have chosen to operationalize the concept of inequality regime. In the next we, first, present the workplace studied; then we explain the categorization of employees in this study and account for the methodology used. Thereafter, we report on particular inequalities found that we believe to be related to certain practices and processes at the Housing Company, answering our first research question. The subsequent section deals with meanings and inequality at the Housing Company and is thus related to the second research question. In the following section, we answer our third research question about how different practices, processes, and meanings are interrelated in reinforcing the local inequality regime. Finally, we present our conclusions.

\section{Operationalizing "inequality regime"}

In this section, we explain how Acker's concept of inequality regime- “interrelated practices, processes, actions and meanings that result in and maintain (...) inequalities within particular organizations"-was operationalized for our empirical study and how we have added analytical components to it. By practice, we understand all kinds of routines that people follow when carrying out their work and otherwise interacting on a daily basis, that is, as "a routinized way in which bodies are moved, objects are handled, subjects are treated, things are described and the world is understood" (Reckwitz, 2002: 250 , in describing a version of practice theory). By processes, we refer to changes in such practices that organizations undergo for one reason or another. Actions are undertakings by individuals or groups that are of shorter duration and that have-for the individuals that act-particular aims. At a workplace, a certain decision to change routines taken by the chief executive officer may, for instance, be of particular importance for the processes. In this study, we are not interested in why certain processes began or how they unfolded but rather which practices and processes affected (in)equality. For that reason, we do not analyze specific actions.

Meaning is crucial to this study, as it is for Acker who uses it to refer to, for instance, how different practices are gendered or ethnified (Acker, 2006b: 69-71). Meaning could be included in the concept of practice, as it is in the definition by Reckwitz above, or could be treated as a separate concept, as in Acker's definition. The choice between including it in the practice concept or not lacks importance for the issue of operationalization. What matters instead is how meaning is captured. Here, "meaning" refers to shared local understandings of things and issues. Further specification of the analysis of 
meaning is still needed though: namely, the meaning of what? We suggest two things for studies of inequality at workplaces. The first, inspired by Acker's work, is the meaning of the relevant separation-in our case, the categorization into natives and immigrantsand how the perceived groups are understood to relate to each other.

Second, we suggest that in a work organization, it is crucial to grasp the meaning of different skills and abilities in relation to the work carried out. People are evaluated and rewarded for what they are understood to bring to the organization. In order to be able to study this aspect appropriately, we use Pierre Bourdieu's concepts of cultural and symbolic capital. The concept of cultural capital has been used in research on how migrants with different backgrounds, knowledge, and skills are treated in the countries they move to (e.g., Lund Thomsen, 2005; Trueba, 2002). Cultural capital refers to knowledge, skills, and ways of acting and behaving that are considered valuable and can be transformed into money (another form of capital) or good jobs (Bourdieu, 1977, 2001). The value of cultural capital, however, is dependent on the context and the owners of capital: the usefulness of the skills for those who possess them varies with the "markets" they are brought to. The concept of symbolic capital (Bourdieu, 1984), the recognition obtained for a skill among a particular group of people (i.e., an aspect of its perceived meaning), is useful for capturing the meaning of particular skills at a workplace. The two concepts of cultural and symbolic capital in combination can be used to study how the usefulness of education, knowledge, and skills for their bearers may vary, depending on the context.

Acker's definition refers to the interrelation of practices, processes, actions, and meanings. To analyze interrelations in order to answer the third research question, we have tried to understand how the different kinds of inequality that we found might strengthen each other, not least through the meaning they obtain at the workplace.

Inequality regimes have different bases of inequality (i.e. the divisions follow class, gender, race, or other lines) and varying forms and degrees of inequality. When we conducted our study, we analyzed inequalities on the basis of both ethnicity and gender (Boréus \& Mörkenstam, 2010). In this article, we only present a partial description of the inequality regime by focusing on the distinction between men with native Swedish background and men with immigrant background.

\section{The workplace, the people studied, and the methods used}

\section{The Housing Company}

A main difficulty in initiating the project was to find a workplace that would allow us to conduct the study without interfering in the gathering of our material or trying to influence our findings. When we approached the Housing Company and presented our research questions, the company was interested, as it had been working for several years with gender equality (and were proud of that work). It gave us full access to the workplace, informed the employees of our presence there, and provided us with the necessary materials (such as lists of wages). This was done on the condition that the external communication of our results was written in a way that maintained the anonymity of the company.

The Housing Company was owned by the municipality and headed by an executive committee consisting of members of the political parties in the municipality and union 
representatives. The company was in a dominant position in the local housing market, and its activities can best be described as that of a Swedish public utility. Many of the tenants had immigrated to Sweden. A chief executive officer (CEO) and a directorate were in charge of daily activities. The company had a head office, where one-third of the employees worked, and several local offices situated in the different residential areas. The head office was dominated by white collar workers, while the majority of the employees in the local offices were blue collar workers employed as property caretakers. Caretakers made up the single largest group of employees at the company (56\%).

\section{Categorization of the employees in the study}

In our analysis, we focus on inequalities between caretakers who were born in Sweden and those who had immigrated to the country after the age of 15 . We have not included caretakers born in Sweden with one or both parents born abroad in the analysis, that is, descendants of immigrants, a group often referred to as "second generation immigrants" (see, e.g., Vera-Larrucea, 2013), since there were too few caretakers with this particular background at the Housing Company. In the text, we consistently refer to the caretakers as "native" and "immigrant" employees. The distinction between immigrants and natives is frequently made in Swedish public discourses. The categories, often referred to as "immigrant" and "Swede," have had high salience since at least the 1970s-when the word "immigrant" replaced the word "foreigner" in the public debate (Mörkenstam, 2010, pp. 590-596; Sainsbury, 2012, p. 215)-arguably much higher salience than various ethnic categories (Boréus, 2006, p. 160). They were also frequently used at this particular workplace, just as at so many others in Sweden.

\section{Methods}

The study had a mixed methods design, composed of the methods presented in Table 1. The data were gathered in different phases during the period 2005-2009, which allowed us to study processes of change.

The core material consists of semi-structured interviews with individual employees. We interviewed 10 of a total of 24 male native caretakers (these interviewees were randomly chosen) as well as 10 of the 11 male immigrant caretakers working in four of the five residential areas. ${ }^{3}$ Nine of the immigrant male employees we interviewed came from Eastern European, Asian, and Latin-American countries, and one from a North European country. The focus was on the employees' experiences of their work days and of different practices at the workplace, with a particular emphasis on what they considered to be obstacles or problems, and what, if anything, they found unfair at the workplace. After the interviews, we administered a short questionnaire concerning the backgrounds of the employees, including education and language skills. We also conducted two small focus groups of relevance for this article, one with native caretakers and one with immigrant caretakers. ${ }^{4}$ The individual interviews, in particular, helped us to locate various kinds of inequalities as well as to understand the workplace practices and certain processes of change and to provide part of the material for analyzing local meanings. With the focus groups, conducted after the individual interviews, we wanted 
Table I Overview of methods and information obtained in the study of the Housing Company

\begin{tabular}{|c|c|}
\hline Method of data collection & Resulting in information on \\
\hline $\begin{array}{l}\text { Individual semi-structured interviews with } \\
\quad-\text { three managers } \\
\quad-10 \text { native male caretakers } \\
\text { - } 10 \text { immigrant male caretakers } \\
\text { carried out between March } 2005 \text { and May } 2007 \text {, } \\
\text { transcribed and analyzed with the help of software } \\
\text { for computer-assisted qualitative data analysis }\end{array}$ & $\begin{array}{l}\text { Inequality in } \\
\quad-\text { perceived influence and job security } \\
\text { - opportunities for capitalizing on useful skills } \\
\text { Practices } \\
\text { Processes } \\
\text { Meanings }\end{array}$ \\
\hline $\begin{array}{l}\text { Questionnaires with the same interviewees } \\
\text { regarding background, education, and language } \\
\text { skills between March } 2005 \text { and May } 2007\end{array}$ & $\begin{array}{l}\text { Inequality in } \\
- \text { opportunities for capitalizing on useful skills }\end{array}$ \\
\hline $\begin{array}{l}\text { Focus groups with caretakers } \\
\quad \text { - one with native male caretakers } \\
\quad \text { - one with immigrant male caretakers } \\
\text { carried out in 2007, transcribed and analyzed } \\
\text { with the help of software for computer-assisted } \\
\text { qualitative data analysis }\end{array}$ & $\begin{array}{l}\text { Inequality in } \\
\quad-\text { perceived influence and job security } \\
\text { Practices }\end{array}$ \\
\hline Observations at 16 staff meetings during 2005-2009 & $\begin{array}{l}\text { Practices } \\
\text { Meanings }\end{array}$ \\
\hline $\begin{array}{l}\text { Informal talks with caretakers and managers and } \\
\text { observation of a few caretakers at work during } \\
\text { 2005-2009 }\end{array}$ & Practices \\
\hline $\begin{array}{l}\text { Survey with } 89 \text { employees on their experiences } \\
\text { of working conditions in } 2009\end{array}$ & Practices \\
\hline $\begin{array}{l}\text { Analysis of documents such as } \\
\quad \text { - lists of wages } \\
\text { - instructions for wage setting }\end{array}$ & $\begin{array}{l}\text { Inequality in } \\
\quad-\text { wages } \\
\text { Practices } \\
\text { Processes }\end{array}$ \\
\hline $\begin{array}{l}\text { Presentations of our results to the directorate } \\
\text { (including local managers) and to all caretakers } \\
\text { in } 2009\end{array}$ & $\begin{array}{l}\text { Practices } \\
\text { Processes }\end{array}$ \\
\hline
\end{tabular}

to enhance our knowledge of certain specific themes that had been highlighted as prevalent in the day-to-day life of the caretakers in the previous interviews. In that way, the focus groups were used primarily to affirm and deepen our understanding of how the employees perceived their workplace.

Our presence at the 16 work meetings with the local manager and the caretakers of the different areas together with the two presentations of our results (one for the directorate including local managers and one for all caretakers) were also important sources for our understanding of the practices at the company. The field notes from the work meetings provided the rest of the material for the analysis of meanings. Our presence at the meetings usually seemed to be forgotten after a short while, and we believe that the conversations followed the normal conventions for how different topics were 
dealt with when staff members of different ethnic backgrounds were present. What was expressed in the interviews and focus groups was more influenced by our presence, and it is to be expected that people were on their guard when issues having to do with categorizing people along the lines of national or ethnic origin-often a sensitive issue in Sweden-were brought up. We did, however, expect to find shared meanings of the workplace being drawn upon in our material, that is, traces of particular "interpretative repertoires" stemming from public discourses when majority ethnic interviewees discussed the culture of the ethnic minority (Wetherell \& Potter, 1992).

The survey on working conditions was administered to all of the employees in the local offices, including caretakers (the majority of employees) and other administrative and technical staff. Over $90 \%$ of the employees answered the survey, which provided information that, in combination with the individual interviews, allowed us to draw conclusions about the consequences of certain disciplinary practices for different groups of employees.

\section{Practices and processes generating inequalities}

Several kinds of inequality were at work at the Housing Company.

\section{Unequal wages}

The topic most frequently mentioned by our informants when asked about injustices was wages. One kind of experience of unfair wages stemmed from what many informants referred to as a nonexplicit requirement for certain language skills: "I can compete with a Swede [...] but the Swede's better paid than I am." One informant recounted that his presumed lack of knowledge of the Swedish language was turned into an explicit negative argument when he tried to obtain a raise during a salary discussion with the local manager: "No, you can't write in Swedish that well' [was the response]. Then, you realize that it is the language that keeps the wage down."

The experience of unfair wages was not equally distributed among the employees. Eight of ten men born in Sweden did not mention any personal experience of injustice (although several mentioned that some immigrant colleagues were treated unfairly), while all 10 male immigrant informants claimed that they had an unfairly low salary. The discontent that the immigrant informants expressed was related to actual wage differences. An analysis of all of the wages at the Housing Company shows that traditional class patterns structured the setting of wages: there were notable differences between managers and other employees as well as differences between white and blue collar workers. Since the majority of the immigrant employees held blue collar jobs, they lost out due to their positions.

We also found support for our informants' experiences of being treated unequally in the same job. The difference in average monthly wage between native and immigrant male caretakers was slightly greater than 650 SEK, or close to $3 \%$ (Table 2). ${ }^{5}$ The wage difference is also clearly seen when viewing the lowest and highest wages within each category.

Table 3 summarizes the relationship between wages and experience in terms of the number of years the caretakers had been employed at the Housing Company. The result 
Table 2 Average monthly wage (SEK) for male caretakers, spring 2007

\begin{tabular}{lccl}
\hline & Average wage & Lowest - highest wage & N \\
\hline Native men & 22,959 & $21,370-25,995$ & 34 \\
\hline Immigrant men & 22,308 & $19,600-23,345$ & 16 \\
\hline
\end{tabular}

Table 3 Average monthly wage (SEK) for male caretakers by number of years employed at the Housing Company, spring 2007

\begin{tabular}{lcccc}
\hline \multicolumn{5}{c}{ Number of years employed } \\
\hline & $\mathbf{0 - 5}$ years & $\mathbf{6 - 1 0}$ years & More than 10 years & $\mathbf{N}$ \\
\hline Native men & 22,752 & 22,951 & 23,061 & 34 \\
\hline Immigrant men & 21,375 & 22,449 & 22,537 & 16 \\
\hline
\end{tabular}

is unequivocal: immigrant men earned less than native men, regardless of how much experience they had.

In sum, no matter how we analyzed wages, immigrant men were the losers, a pattern representative of housing companies in general in Sweden. ${ }^{6}$ The wages at this particular workplace thus followed larger societal structures, with native men earning more than immigrant men (and more than women) in the same job. Moreover, our study confirms results from previous research in other Swedish workplaces: being employed longer than native men does not generate a higher salary for immigrants (e.g., Augustsson, 1996).

\section{Unequal possibilities: ethnic division of labor?}

We analyzed the distribution of positions for all of the employees of the Housing Company (Table 4). Immigrants were underrepresented as managers. No one in the directorate had immigrated to Sweden, and the only immigrant manager held a rather low position in the company hierarchy. Furthermore, there were no immigrant employees in typical white collar positions (HR, economic administration, technical support).

Table 4 Job positions for natives and immigrants (men and women), autumn 2007

\begin{tabular}{lcccccc}
\hline & $\begin{array}{c}\text { Directors } \\
\text { and other } \\
\text { managers }\end{array}$ & $\begin{array}{c}\text { Human } \\
\text { resources, } \\
\text { economic } \\
\text { administration }\end{array}$ & $\begin{array}{c}\text { Technical } \\
\text { support }\end{array}$ & $\begin{array}{c}\text { Reception, Caretakers } \\
\text { incident } \\
\text { reports/ } \\
\text { complaints } \\
\text { contact with } \\
\text { employees }\end{array}$ & All \\
\hline Natives & $9(90 \%)$ & $15(100 \%)$ & $13(100 \%)$ & $8(80 \%)$ & $45(73 \%)$ & $90(82 \%)$ \\
\hline Immigrants & $1(10 \%)$ & - & - & $2(20 \%)$ & $17(27 \%)$ & $20(18 \%)$ \\
\hline
\end{tabular}


This pattern at the Housing Company is-once again-representative for Swedish housing companies and reflects the labor market in general in Sweden. ${ }^{7}$ Immigrants are underrepresented in all job types, with the exception of craftsmen and in occupations wherein there is no educational requirement (see, e.g., Näringsdepartementet [Ministry of Economy], 2000).

This ethnically biased distribution of positions may discourage immigrant men from applying for white collar positions at the head office; they might perceive the existence of a "glass ceiling" within the Housing Company (Fooley et al., 2002). One informant explicitly stated that he refrained from applying for an administrative job at the head office since he was convinced he would get a negative reply:

No, since it's unrealistic, you know, you've been there yourself [at the head office], you see there are no immigrants working there. So I'm not talking bullshit, that's the way it is, that's reality [...] I don't try because why would I apply, when I'm going to get a 'no'.

The company went through a major reorganization in 2006, involving changes in the job duties of caretakers. When we initiated our project, everyone had basically the same responsibilities: administrative tasks, technical/practical repairs, maintenance of the outdoor environment in the residential areas, and contact/communication with the tenants. The reorganization divided the position of caretaker into three: one responsible for the outdoor environment (outdoor caretaker); one responsible for the rental of apartments, including contact with the tenants and administration (apartment caretaker); and, one responsible solely for technical services (repairs). Was there a pattern in terms of what new roles native and immigrant caretakers were assigned?

As summarized in Table 5, a majority of the immigrant men were assigned the role of outdoor caretaker or repairman. Among those with the role that required the most contact with tenants and included a number of different administrative tasks-apartment caretakers-immigrant men were underrepresented.

Table 5 Job positions for natives and immigrants (men and women), former caretakers, autumn 2007

\begin{tabular}{lcccc}
\hline & $\begin{array}{c}\text { Apartment } \\
\text { caretakers }\end{array}$ & $\begin{array}{c}\text { Outdoor } \\
\text { caretakers }\end{array}$ & Repairmen & All caretakers \\
\hline Natives & $17(89 \%)$ & $14(67 \%)$ & $10(66 \%)$ & $41(71 \%)$ \\
\hline Immigrants & $2(11 \%)$ & $7(33 \%)$ & $8(44 \%)$ & $17(29 \%)$ \\
\hline
\end{tabular}

Our analysis thus indicates that there was an ethnic division of labor at the Housing Company. With the reorganization, the segregation between native and immigrant caretakers increased. This could indicate inequality of opportunities, with a larger variety of positions open to native employees.

\section{Unequal influence and unequal feelings of job security}

In the interviews, we asked questions regarding the informants' possibilities of influencing their personal working conditions and what they thought about their possibilities of influencing the workplace in general. 
An important aspect of influence over individual working conditions, according to our informants, was the possibility of choosing what area to work in. Even more important to some was avoiding being sent to an area where they did not want to work, something that happened on a regular basis. According to the questionnaire administered in 2009 , slightly more than $20 \%$ of the employees working in the local residential areas had an experience of being sent to a particular area to work, even though they had told their local managers that they did not want to work there. These unwanted transfers were often understood by the employees as punishment on the part of the managers. In our interviews, these transfers were frequently mentioned by the immigrant men and were obviously perceived as an implicit threat. Among the native male informants, such transfers were rarely mentioned. In the responses to our questionnaire, however, there was no significant difference between native and immigrant employees in reporting having actually been transferred against their will. We return to this finding below.

There were pronounced inequalities in the employees' perceptions of being able to influence the workplace in general and its routines. In order to feel that you can exert influence, several conditions must be fulfilled: (1) you must be confident enough to voice your opinions at all, for instance at work meetings, (2) you must feel that you are allowed to express criticism and make proposals, and (3) you must believe that you are being listened to and that something may actually result from your attempts at influencing.

We have no systematic evidence to indicate that the confidence to voice opinions at meetings, and so on-condition (1)—was unequally distributed. Some immigrant informants stated that, for a person whose native language is not Swedish, this might be difficult:

You don't get through. But as a Swede, you know, there isn't a problem for her or him. It doesn't matter if they've done a rather lousy job, some claim anyway that they've done a good job. They can explain. But for a poor immigrant it's a bit difficult to explain yourself.

If you have the courage to speak at meetings, you still have to feel secure enough to express criticism and to come up with proposals that might not be popular with the management if you want to influence the situation-condition (2). Some informants claimed that anyone could express criticism and make suggestions at meetings and to the management without taking a risk: "we are honest, we stand up for our opinions," as one native caretaker claimed. Quite a few informants, however, did not share this positive assessment and expressed outright fear of being critical. None of these were native men. Several immigrant men stated that they withheld criticism for fear of negative consequences if they voiced it. One stated: "Not that I'm critical of the company, but if I'd express criticism it might be difficult. Perhaps I'd get sacked!"

The questionnaire administered in 2009 also revealed a clear pattern, according to which native men felt more secure about expressing criticism than immigrant men (even though the same proportion of native and immigrant men expressed fear of negative consequences) (Table 6).

Even if you have the courage to speak up at meetings and consider it safe to express criticism and make suggestions, this still does not entail having influence. Having influence also entails that your attempts at changing things are actually successfulcondition (3)-at least sometimes. Our results are not completely consistent with regard 
Table 6 Answers to the question "Are you scared of expressing criticism at meetings or to managers?", June 2009

\begin{tabular}{lcccc}
\hline & Not afraid & $\begin{array}{c}\text { Feel a certain } \\
\text { reticence }\end{array}$ & $\begin{array}{c}\text { Afraid of negative } \\
\text { consequences }\end{array}$ & Total (N) \\
\hline Native men & $26(70 \%)$ & $7(19 \%)$ & $4(11 \%)$ & $37(100 \%)$ \\
\hline Immigrant men & $7(36 \%)$ & $10(53 \%)$ & $2(11 \%)$ & $19(100 \%)$ \\
\hline
\end{tabular}

to this aspect of having influence. The questionnaires did not indicate systematic differences in judgments as to whether one could influence the workplace and its organization, but in the interviews, immigrant men, in particular, expressed the view that they were not listened to:

You are free to express what you think and find appropriate. OK, but whether it ultimately counts is a different story. [...] it doesn't have the same weight as the words of a Swede. [...] those things for instance [referring to criticism he has voiced himself], they don't listen to.

Occasionally, the topic of discrimination came up in the interviews. Some immigrant caretakers felt discriminated against by the Housing Company, though most did not make statements to that effect. Several immigrant and native caretakers as well as one manager did report that immigrant caretakers were sometimes discriminated against by tenants that held prejudicial attitudes. One caretaker reported that: "I was badly treated by the tenants, partly in a clearly racist way, so to speak. By not being accepted. Some expressed explicitly that they wanted me and [colleague $\mathrm{x}$, also an immigrant caretaker] to leave their apartments because we weren't welcome." Other studies of working life also report that employees who appear to be "non-Swedish" experience racism and discrimination from clients, patients, and so on (Olsson, 2000, pp. 33-34; Sörensdotter, 2008, pp. 212-215). Immigrant caretakers talked about experiences of discrimination in other spheres of life, outside of the company, as well. Such experiences, together with the fact that the "non-Swedish" employees constituted a minority at the workplace, were likely to be related to feelings of insecurity in the work situation that several of the immigrant interviewees expressed. We think that this is also the explanation for immigrant employees reacting more strongly to-and, therefore, more often bringing up in our interviews - the forced transfers that native employees also had to cope with.

The study thus indicated that immigrant male caretakers considered themselves to have less influence and felt less secure at the Housing Company than did native ones. These kinds of inequalities are more difficult to compare to Swedish workplaces in general than the forms of inequality mentioned earlier, since there is hardly any comparative aggregate data available. Several studies show, however, that many immigrants in Sweden experience marginalization, exclusion, and discrimination in the labor market in general, in their daily work and in a variety of other societal contexts (see e.g., Arai \& Skogman Thoursie, 2009; Behtoui \& Neergaard, 2009). 


\section{Inequality-generating practices and processes}

We registered several kinds of practices that resulted in and reproduced inequality, also highlighted by Acker (2006b, pp. 112-124). The wage-setting practices at the Housing Company were individual, something that seems to increase inequality between groups (Acker, 2009). Even the explicit criteria for setting wages as defined by the company (which also served as a starting point in meetings between the local manager and the individual employees in discussions of the latter's wages) seemed to contribute to inequality. One criterion was, for instance, called "general competence" and included creativity, having ideas, taking initiative, and showing an interest in developing oneself and the workplace. All of these are criteria that would put a person that is less confident in being able to influence and that is afraid of voicing criticism at a disadvantage. Furthermore, the manner in which supervision was exercized, and compliance secured was of importance for the maintenance of the inequality regime. As indicated above, one way in which the managers secured compliance was by systematically moving caretakers from one local area to another. Several caretakers also felt a threat of losing their jobs. This does not explain directly how inequality between natives and immigrants was maintained, but native men seemed less sensitive to certain kinds of pressure than immigrant men.

The practices described above go some way in explaining inequality in incomes and possible inequality in access to different jobs. The organizing processes in themselves, that is, how work was organized into different jobs and hierarchies, were also of importance. The reorganization of jobs that took place led, as we could see, to stronger ethnic workplace segregation. In the next part, we will turn to the effect of the shared local understandings of things and issues, that is, meaning, in explaining the inequalities found.

\section{Meaning}

In this part, we will shed some light on the local meaning, first, of the separation into natives and immigrants and, second, of different skills and abilities that people were using-or were expected to use-in their work.

\section{The separation into natives and immigrants}

A number of studies of how "non-Swedes" are discursively constructed or treated in different public arenas have been conducted, among them studies of newspapers (Brune, 2004; Mattsson, 2001), of election propaganda (Boréus, 2006, 2013), and of scientific texts (Mattsson, 2001; Torres, 2007) as well as of parliamentary speeches, investigations, and other official documents (Carbin, 2010; Johansson, 2006; Mörkenstam, 2010). These studies reveal two things of relevance for our study. Firstly, "immigrants" are frequently sorted into one category and "Swedes" into another, and these categories are often constructed as mutually exclusive. Secondly, several of the studies referred to show that those categorized as immigrants are often problematized and associated with negatively valued phenomena, such as welfare dependence, unemployment, and crime. This finding is in line with studies of the public sphere in other countries (e.g., van Dijk 
1993 who presents a comparative study of racism in elite discourses in the Netherlands, Great Britain, Germany, France, and the United States). The way "immigrants" are discursively constructed and discussed in the public sphere is, however, not necessarily mirrored by the way we categorize and give meaning to categories of people that we know and interact with. There may, though, be some connection.

A first result of our study was that the categories referred to as "Swede" and "immigrant" were at work in daily life at the company, but that the categories were more important in discussions of tenants than of staff. It was, for instance, considered to be of importance whether there were a majority of "Swedes" or of "immigrants" living in the various residential areas of the company, and the areas were often characterized by the proportion of immigrants living there. A residential area could be described as being a "mixed, rather mixed area. There are immigrants but there is not a strong concentration of immigrants, but they are there." "Concentration of immigrants" (invandrartätt, in Swedish) was often used as a descriptor, an expression that is used in the public debate as well, often in conjunction with poverty, deprivation, and concerns over social cohesion, as in many European countries (e.g., Phillips, 2009).

We found few examples of the categorizations "Swede"/"immigrant" being used between or about colleagues. These categories had no overt function in dealing with daily work and thus did not need to be referred to (in the same way that it was necessary to categorize people as, for instance, "caretakers" or "tenants"). In a study of a multi-ethnic home for elderly, it was shown how daily work led to the use of a category referred to as "Spanish-speaking"; there was a division of labor according to which Spanish-speaking staff members dealt with Spanish-speaking tenants (Olsson, 2000). At the Housing Company, the language competence of the staff was used to communicate with tenants who did not understand Swedish well, but this practice was not considered important enough for this kind of semi-ethnic categorization to develop.

A second result of the analysis is that there was, in line with the research on public texts referred to above, a certain tendency to problematize those categorized as "immigrants." Although this problematization was more often directed at tenants than employees, we did on two occasions hear derogatory jokes about a colleague's ethnic background, and some native caretakers did problematize immigrant colleagues in the interviews. These native caretakers claimed, for instance, that some immigrant colleagues were difficult to understand, which made some aspects of work more difficult, and that their own workloads, therefore, increased. Furthermore, some native caretakers were upset when their immigrant colleagues spoke to each other at work in their native language: "We don't like when they speak [language $\mathrm{x}$ ] here at work", as one native caretaker said: "It is disrespectful in a way [...] and he has been here for 25 years and speaks Swedish very badly, I think that is something to be ashamed of [...]."

The tenants and the residential areas described as having a "concentration of immigrants" were much more frequently referred to as problematic. A high proportion of immigrants was associated with unspecified problems, as when one of the native caretakers stated that she had worked in two different residential areas with a high "concentration of immigrants" before and did not want to be sent to another one. That was not the full story, however, since the "concentration of immigrants" was not necessarily conceptualized as a problem. Some caretakers preferred to work in these areas and described the immigrant tenants as more friendly and grateful for the caretakers' work than other ("Swedish") tenants. 
In sum, we noted that the important sorting of people into either the category "Swede" or the category "immigrant" was at work, although less so when colleagues were talked about than when tenants were the topic. Moreover, there were at least tendencies for the immigrant staff minority to be conceived of as problematic by their native colleagues. This aspect of meaning should be understood as part of the inequality regime, since local discourses thus emphasize the difference between non-native men as a group and the privileged native men, being the "standard."

\section{Unequal opportunities for capitalizing on useful skills}

To capture the meaning of different skills and abilities that people were using, or were supposed to use, we asked in the interviews what one needed to be good at as a caretaker. Two things frequently came up: that you needed to have "social competence" and that you needed to be practical, good with your hands. Something that was never mentioned as important was a particular skill that the group of immigrant caretakers possessed to a higher degree than the native ones and that was of particular use: relevant language skills. While the average native caretaker interviewee claimed to speak Swedish and one other language, usually English, the average immigrant caretaker interviewee reported speaking three languages: the native language, Swedish, and a third (and sometimes even a fourth and a fifth) language.

The utility of this skill was revealed to us more by chance when the informants were asked to tell us about a normal work day. The linguistic competence that most immigrant caretakers possessed was useful, since the languages they spoke in addition to Swedish were often languages of groups of tenants, many of whom had difficulties expressing themselves in Swedish or understanding the Swedish spoken by the staff. Problems of communication between staff and tenants were referred to in many interviews. All of the immigrant male caretakers that were asked about this reported that they frequently used their knowledge of languages other than Swedish: "there are occasions when they [colleagues] are having a little conversation or discussion in the laundry room and then they hand [the tenant] the telephone so that we should act as interpreters and explain to them in a better way." Others reported that they used to get phone calls from the head office as well as from colleague caretakers wanting them to interpret when there were problems getting through to a tenant in Swedish. A few native caretakers also pointed out the usefulness of their colleagues' language competence.

Thus, immigrant caretakers frequently used their language skills in their daily work, and these were made use of by the company. The caretakers were, however, not able to turn this cultural capital into economic capital. As shown above, they earned less than their native colleagues. They themselves did not count on being rewarded for their language skills when it came to wages: "No, it's not a merit. I've never heard that it's great that you know a language. [...] Nobody ever said to me, that, gee, how good that we've a person that speaks [language $\mathrm{x}$ ]." On the contrary, some of the immigrant caretakers believed that the fact that they did not speak Swedish the way natives did was something that affected their salaries negatively, as shown above.

The immigrant caretakers were thus not rewarded for their useful language skills, something well in accordance with previous research in Sweden (Kamali, 2005) and with studies of workplace segregation in general (Hellerstein \& Neumark, 2008). It was 
not possible to capitalize on this knowledge that was specific to the immigrant employees, while it might have been possible to capitalize on a language skill that was specific to the natives: speaking Swedish as natives do. These results should not come as a surprise. Bourdieu refers to "linguistic capital" as a particular kind of cultural capital, the value of which varies with the context (Bourdieu, 1984). That this kind of linguistic competence did not generate economic capital is best explained by its inability to generate symbolic capital, that is, the meaning of the competence was not that it was worth money. Thus, the meaning of this skill can be said to have contributed to the inequality regime.

\section{How interrelations between inequalities reinforce the inequality regime}

We believe that the practices, processes, and meanings of the workplace interacted in ways so that the different kinds of inequality reinforced each other. One likely connection is between inequality in job security and confidence in being able to exert influence. de los Reyes (2007) provides several examples of how immigrants at another kind of workplace expressed insecurity in relation to native managers or colleagues when they did not know how to interpret the negative behavior they experienced: were they facing discrimination as "non-Swedes," or was the behavior due to something else? We do not know whether immigrant men actually risked more than native men when expressing criticism, but the very feeling that this might be the case could be enough to diminish a person's possibility to influence: if you are afraid of expressing criticism and if you do not think that you can influence, you are more likely to refrain from trying. Thus, those practices that affect job security - such as threats of getting sacked and the disciplinary replacement of staff members-might actually diminish possibilities of influencing more for certain groups, even if the practices are directed equally toward all employees. Those most affected are the ones with previous negative experiences and perhaps also those that are looked upon as exceptions to a normalized majority group (see, e.g., Vallas et al., 2009).

There were also other practices in operation that might have been constantly undermining the confidence of immigrant caretakers. Discourses that tended to problematize them, if these were noticed, could be one. Another could be the possibility of capitalizing on being able to speak and write Swedish the way natives do but not on competence in other languages. Together with a lack of confidence, this is likely to go together with a feeling of having poor chances of influencing one's place of work. And this, in turn, can affect an employee's chances of raising her or his salary, if what is being rewarded is being a person that makes a difference at the workplace. This was, as we described above, one of the most important criterion used in setting wages, according to the company.

Thus, practices that undermine the feeling of security for some groups can have the indirect effect of keeping the wages of these groups down. This may well represent a vicious circle. The frequency with which informants returned to the issue of wage inequalities indicates that what was considered important was not only the money as such but also the feeling of unfairness. The informants most likely concluded that unequal pay represented their unequal value in the eyes of their employer. This is a feeling that might also undermine one's confidence as an employee. 


\section{Conclusion}

We have presented a study of a specific, yet typical, Swedish workplace. Our results illustrate the two patterns of inequality that we highlighted in the Introduction: that disadvantages come in clusters and that different groups tend to be either advantaged or disadvantaged in multiple ways. At this workplace, native men enjoyed an array of advantages, while immigrant men were left with an array of disadvantages: native men earned more at the same job, seemed to have broader access to the various areas of responsibility that the position of caretaker was divided into, felt more confident that they could exert influence, seemed to be less insecure in their work environment, found it easier to speak out critically, could potentially capitalize on a competence that the immigrant caretakers could hardly have (the ability to speak and to write Swedish the way natives do), and belonged to the ethnic group that was privileged in public discourses and perhaps also in local discourses.

In response to our first research question about inequality-generating processes and practices, we pointed to the wage-setting routines as well as to the way compliance was secured by the management. The wage criteria seemed to reward employees already in a secure position, while the actions on the part of the managers understood as disciplinary by the staff would have created the most pressure on those who already felt themselves to be in a less secure position.

The second research question considered the role of local meanings in generating inequality. We found the usual Swedish categorization into "Swedes" and "immigrants" and a certain problematization of immigrant caretakers by their native colleagues, although not at all as pronounced when colleagues were talked about as when it came to the tenants. In analyzing the meaning of different skills and abilities, we found that the particular linguistic skills that many immigrant caretakers had could not be turned into symbolic capital, while it was possible that the ability to use Swedish as a native could be used that way.

In response to our third research question on how different practices were interrelated in this particular inequality regime, we offered an interpretation of how certain inequalities might have worked to strengthen others where wage-setting practices and ways of disciplining the staff were pointed out as important.

We hope that this study has shown that it might be rewarding to carry out detailed studies of what generates inequality at particular workplaces and that Acker's concept of inequality regime is a suitable analytic tool, especially when focusing on certain aspects of meaning. We also hope to have demonstrated that Bourdieu's concepts of cultural and symbolic capital enrich the analysis of these aspects of meaning.

An important last point we want to make is that if we neglect the subtle and colloquial forms of inequalities that interact and reinforce each other, the clearly observable differences in wages run the risk of being interpreted in terms of individual characteristics of each employee instead of in terms of inequality (or discrimination). The gut reaction from the managers when we presented our results was to describe the wage inequalities they could not deny being based on the employees performance on an individual level: each employee received the wage that $\mathrm{s} / \mathrm{he}$ deserved in accordance with the wage criteria of the company (although they actually started out by denying the existence of any pattern of wage inequality). It is thus when these different forms of inequality are analyzed at the same time-how they are interrelated - that the pattern of inequality, or the inequality 
regime, becomes apparent. One way of describing the inequality regime is to use the metaphor of political theorist Iris Marion Young in her discussion of structural oppression, to compare these different forms of inequality to the wires of a birdcage. If we look at a bird in a cage and only see one wire at the time, we can never understand why the bird does not fly away. Only when we see how the wires are connected to enclose the bird may we "explain why the bird is unable to fly freely" (Young, 2000: 93).

\section{References}

Acker, J. (2000) Revisiting Class: Thinking from Gender, Race, and Organizations, Social Politics 7(2): 192-214. doi: http://dx.doi.org/10.1093/sp/7.2.192.

Acker, J. (2006a) Inequality Regimes. Gender, Class and Race in Organizations, Gender and Society 20(4): 441-64. doi: http://dx.doi.org/10.1177/0891243206289499.

Acker, J. (2006b) Class Questions: feminist answers. Lanham: Rowman \& Littlefield.

Acker, J. (2009) From Glass Ceiling to Inequality Regimes, Sociologie du travail 51(2): 199_ 217. doi: http://dx.doi.org/10.1016/j.soctra.2009.03.004.

Andersson, R., Å. Bråmå \& E. Holmqvist (2010) Counteracting Segregation: Swedish Policies and Experiences, Housing Studies 25(2): 237-56. doi: http://dx.doi.org/10.1080/ 02673030903561859.

Arai, M. \& P. Skogman Thoursie (2009) Renouncing Personal Names: An Empirical Examination of Surname Change and Earnings, Journal of Labor Economics, 27(1): 127-47. doi: http://dx.doi.org/10.1086/59396.

Augustsson, G. (1996) Etniska relationer $i$ arbetslivet [Ethnic relations in working life]. Umeå: Sociologiska institutionen, Umeå universitet.

Behtoui, A. \& A. Neergaard (2009), Perception of Discrimination in Recruitment and the Workplace, Journal of Immigrant and Refugee Studies, 7:347-69. doi: http://dx.doi.org/ 10.1080/15562940903378813.

Boréus, K. (2006) Diskrimineringens retorik. En studie av svenska valrörelser 1988-2002 [The rhetoric of discrimination. A study of Swedish electoral campaigns 1988-2002], SOU 2006: 52. Stockholm: Fritzes.

Boréus, K. (2013) Nationalism and discursive discrimination against immigrants in Austria, Denmark and Sweden. In Rightwing Populism across Europe: Discourse and Politics, edited by R. Wodak, M. KhosraviNik and B. Mral, 293-307. London: Bloomsbury.

Boréus, K. and U. Mörkenstam (2010) Spjälorna i buren. En arbetsplatsstudie av ojämlikhet mellan kvinnor och män, invandrade och infödda [The wires in the birdcage. A workplace study of inequality between women and men, immigrants and natives]. Lund: Studentlitteratur.

Bourdieu, P. (1977) Outline of a Theory of Practice. Cambridge: Cambridge University Press.

Bourdieu, P. (1984) Vad vill det säga att tala? Det språkliga utbytets ekonomi [What does it mean to speak? The economics of linguistic exchange], Skeptron 1:27-59.

Bourdieu, P. (2001) The forms of capital. In Handbook of Theory and Research for the Sociology of Education, edited by J.G. Richardson, 242-58. Westport, CT: Greenwood Press.

Brune, Y. (2004) Nyheter från gränsen. Tre studier i journalistik och "invandrare”, flyktingar och rasistiskt våld [News from the border. Three studies on journalism and "immigrants", refugees and racial violence]. Göteborg: Göteborgs universitet.

Carbin, M. (2010) Mellan tystnad och tal. Flickor och hedersvåld i svensk offentlig politik [Between silence and speaking. Girls and honour violence in Swedish public policy]. Stockholm: Stockholms universitet.

Carter, J. (2003) Ethnicity, Exclusion and the Workplace. Basingstoke: Palgrave Macmillan. 
Dahlstedt, M. (2005) Reserverad demokrati: Representation i ett mångetniskt Sverige [Reserved democracy. Representation in a multiethnic Sweden]. Umeå: Boréa.

de los Reyes, P. (2007) Att segla i motvind. En kvalitativ undersökning om strukturell diskriminering och vardagsrasism inom universitetsvärlden [To sail against the wind. A qualitative analysis on structural discrimination and everyday racism within academia], Arbetsliv i omvandling, 2007: 5, Arbetslivsinstitutet.

Demker, M. (2012) Positiv attityd till invandring trots mobilisering av invandringsmotstånd [Positive attitudes towards immigration despite mobilization against immigration]. In I framtidens skugga, edited by L. Weibull, H. Oscarsson \& A. Bergström, 95-105. Göteborgs universitet: SOM-institutet.

Ekberg, J. (2006) Försvårar arbetsrätten för invandrarna? [Is the labor law obstructing immigrants?]. In Arbetsrätt, rörlighet och tillväxt, edited by D. Rauhut \& B. Falkenhall, 139-54. Östersund: A2005: 16, ITPS.

Eurobarometer (2012). Discrimination in the EU in 2012. Special Eurobarometer 393.

Fooley, S., D.L. Kidder \& G.N. Powell (2002), The Perceived Glass Ceiling and Justice Perceptions: An Investigation of Hispanic Law Associates, Journal of Management 28(4): 471-96. doi: http://dx.doi.org/10.1016/S0149-2063(02)00140-X.

Hellerstein, J. K. \& D. Neumark (2008), Workplace Segregation in the United States: Race, Ethnicity, and Skill, The Review of Economics and Statistics, 90(3): 459-77. doi: http://dx.doi.org/10.1162/rest.90.3.459.

Hooijer, G. \& G. Picot (2015) European Welfare States and Migrant Poverty. The Institutional Determinants of Disadvantage, Comparative Political Studies, 1-26. doi: http://dx.doi.org/0010414015597508.

Johansson, C. (2006) Välkomna till Sverige? Svenska migrationspolitiska diskurser under 1900-talets andra hälft [Welcome to Sweden? Discourses on migration in Sweden during the second half of the 20th century]. Linköping: Linköpings universitet.

Kamali, M. (2005) Sverige inifrån - Röster om etnisk diskriminering [Sweden from within voices on ethnic discrimination]. SOU 2005: 69. Stockholm: Fritzes.

Kamali, M. (2006) Integrationens svarta bok. Agenda för jämlikhet och social sammanhålning [The black book on integration. An agenda for equality and social unity]. SOU 2006: 79. Stockholm: Fritzes.

Kesler, C. (2015) Welfare States and Immigrant Poverty: Germany, Sweden, and the United Kingdom in Comparative Perspective, Acta Sociologica 58(1): 39-61. doi: http://dx.doi.org/10.1177/0001699314560238.

Le Grand, C. \& R. Szulkin (2002), Permanent Disadvantage or Gradual Integration: Explaining the Immigrant-Native Earnings gap, Labour 16(1): 37-64. doi: http://dx.doi. org/10.1111/1467-9914.00186.

Leicht, K.T. (2008) Broken Down by Race and Gender? Sociological Explanations of New Sources of Earnings Inequality, Annual Review of Sociology 34: 237-55. doi: http://dx. doi.org/10.1146/annurev.soc.34.040507.134627.

Lund Thomsen, T. (2005) Immigrant Entrepreneurship as Gendered Social Positions: A Study of Motivations and Strategies in a Biographical Perspective. Aalborg: AMID; Aalborg University.

Lundborg, P. (2013) Refugees' Employment Integration in Sweden: Cultural Distance and Labor Market Performance, Review of International Economics 21(2), 219-232. doi: http://dx.doi.org/10.1111/roie.12032.

Mattsson, K. (2001) (O)likhetens geografier - Marknaden, forskningen och de andra [The geographies of difference - the market, research and the other]. Uppsala: Uppsala universitet.

MIPEX [Migrant Integration Policy Index] (2015) Countries, Available at: http://www.mipex.eu/sweden. [Accessed September 20, 2015]. 
Molina, I. (1997) Stadens rasifiering. Etnisk boendesegregation i folkhemmet [The racialization of the city. Ethnic segregation of residents in the People's Home]. Uppsala: Uppsala universitet.

Mulinari, P. (2007) Maktens fantasier \& servicearbetets praktik - arbetsvillkor inom hotell- och restaurangbranschen i Malmö [The fantasies of power \& the practice of service work - working conditions within the hotel and catering industry in Malmö]. Linköping: Linköpings universitet.

Myrberg, G. (2007) Medlemmar och medborgare. Föreningsdeltagande och politiskt engagemang $i$ det etnifierade sambället [Members and citizens. Participation in associations and engagement in the ethnified society]. Uppsala: Uppsala universitet.

Mörkenstam, U. (2010) Ekonomi, kultur och jämlikhet: teman i svensk politik i invandrarfrågor decennierna efter det andra världskriget [Economy, culture and equality: rhetorical themes in Swedish immigration policy the decades after WWII], Historisk tidskrift för Finland 95(4): 572-607.

Näringsdepartementet [Ministry of Economy] (2000) Invandrare på den svenska arbetsmarknaden - vistelsetidens betydelse [Immigrants on the Swedish labor market - the importance of the period of residence]. Stockholm: Näringsdepartementet.

Olsson, E. (2000) Behind Doors: Social categorization in a multiethnic care setting for the elderly. Umeå/Norrköping: MERGE Papers on transcultural studies, No. 1/00.

Phillips, D. Minority Ethnic Segregation, Integration and Citizenship: A European Perspective, Journal of Ethnic and Migration Studies 36(2): 209-25. doi: http://dx.doi.org/10.1080/ 13691830903387337.

Reckwitz, A. (2002) Toward a Theory of Social Practices: A Development in Culturalist Theorizing, European Journal of Social Theory, 5(2): 243-263. doi: http://dx.doi.org/ $10.1177 / 13684310222225432$.

Sainsbury, D. (2012) Welfare States and Immigrant Rights. The Politics of Inclusion and Exclusion. Oxford: Oxford University Press.

Schierup, C-U. \& S. Paulson (eds.) (1994) Arbetets etniska delning. Studier från en svensk bilfabrik [The ethnic division of work. Studies from a Swedish auto plant]. Stockholm: Carlssons.

Sen, A. (1997) Inequality, Unemployment and Contemporary Europe, International Labour Review 136(2): 155-172.

Smith Nielsen, S. \& A. Krasnik (2010) Poorer Self-Perceived Health Among Migrants and Ethnic Minorities Versus the Majority Population in Europe: a systematic overview, International Journal of Public Health 55: 357-71. doi: http://dx.doi.org/10.1007/s00038-010-0145-4.

Soininen, M. (2011) Ethnic inclusion or exclusion in representation? Local candidate selection in Sweden. In The Political Representation of Immigrants and Minorities, edited by K. Bird, T. Saalfeld \& A.M. Wüst, 145-63. London: Routledge.

SOU 2000: 41, Välfärd, ofärd och ojämlikhet [Welfare, ruin and inequality]. Available at: http://www.regeringen.se/rattsdokument/statens-offentliga-utredningar/2000/11/sou200041/. [Accessed September 20, 2015].

Szulkin, R. \& J. O. Jonsson (2007) Ethnic Segregation and Educational Outcomes in Swedish Comprehensive Schools, Working Paper 2. Stockholm: SULCIS.

Sörensdotter, R. (2008) Omsorgsarbete i omvandling. Genus, klass och etnicitet inom hemtjänsten [Welfare service work in transformation. Gender, class and ethnicity in the home care service]. Stockholm: Makadam.

Torres,S.Elderly Immigrants in Sweden: “Otherness”Under Construction, Journalof Ethnicand Migration Studies, 32(8): 1341-58. doi: http://dx.doi.org/10.1080/13691830600928730.

Trueba, H. T. (2002) Multiple Ethnic, Racial and Cultural Identities in Action: From Marginality to a New Cultural Capital in Modern Society, Journal of Latinos and Education 1: 7-28. doi: http://dx.doi.org/10.1207/S1532771XJLE0101 2. 
Vallas, S. P., W. Finlay \& A.S. Wharton (2009) The Sociology of Work: Structures and Inequalities. Oxford: Oxford University Press.

van Dijk, T. (1993) Elite Discourse and Racism. Newbury Park: SAGE.

Vera-Larrucea, C. (2013) Citizenship by citizens: First generation nationals with Turkish ancestry on lived citizenship in Paris and Stockholm. Stockholm: Stockholm Studies in Politics 150.

Wetherell, M. \& J. Potter (1992) Mapping the language of racism: discourse and the legitimation of exploitation. New York: Columbia University.

Young, I. M. (2000) Inclusion and Democracy. Oxford: Oxford University Press.

Åslund, O. \& O. Nordström Skans (2010) Will I See You at Work? Ethnic Workplace Segregation in Sweden, 1985-2002, Industrial and Labor Relations Review 63(3): 471-93.

\section{End notes}

${ }^{1}$ We would like to extend our sincere appreciation to all of the informants.

${ }^{2} \mathrm{SOU}$ is an abbreviation of Statens Offentliga Utredningar, Swedish Government Official Reports.

${ }^{3}$ We only gained access to the fifth area at a very late stage of the project.

${ }^{4}$ We also conducted interviews with female caretakers, among them the only one with an immigrant background, and a focus group with female caretakers. These results are reported in Boréus and Mörkenstam (2010). One reason for basing this article solely on a comparison between male caretakers of different national/ethnic origin is thus that there was just one female immigrant caretaker in the residential areas we studied.

${ }^{5}$ We would like to thank Ilkka Henrik Mäkinen and Per Lundborg for their assistance with the quantitative analysis.

${ }^{6}$ In the housing companies, men born abroad (in non-Nordic countries) earned almost 1,000 SEK per month less on average than men born in Sweden, while women earned slightly more than 2,000 SEK per month less than men (Statistics Sweden, dataset 2007).

${ }^{7}$ In $2007,4.5 \%$ of the employees in housing companies in Sweden were born abroad (not including Nordic citizens), while only slightly more than $1 \%$ held leading positions (Statistics Sweden, dataset 2007). 